\title{
Self-assembled ruthenium and osmium nanosystems display potent anticancer profile by interfering with metabolic activity
}

\author{
Mickaël Marloye, ${ }^{a}$ Haider Inam, ${ }^{b}$ Connor J. Moore, ${ }^{b}$ Tyler R. Mertens, ${ }^{c}$ Aude Ingels, ${ }^{d}$ Marilin Koch, ${ }^{f}$ \\ Michal O. Nowicki, ${ }^{f}$ Véronique Mathieu, ${ }^{d, e}$ Justin R. Pritchard, ${ }^{b}$ Samuel G. Awuah, ${ }^{c}$ Sean E. Lawler, ${ }^{f}$ \\ Franck Meyer, ${ }^{a}$ François Dufrasne, ${ }^{a}$ Gilles Berger ${ }^{\mathrm{a}, \mathrm{f},{ }^{*}}$
}

\section{${ }^{*}$ Author for correspondence}

[a] Dr. Mickaël Marloye, Prof. Dr. Franck Meyer, Prof. Dr. François Dufrasne, Prof. Dr. Gilles Berger, Microbiology, Bioorganic \& Macromolecular Chemistry, Faculté de Pharmacie, Université libre de Bruxelles (ULB), Boulevard du Triomphe, 1050 Brussels, Belgium. E-mail: gilles.berger@ulb.be

[b] Inam Haider, Connor J. Moore, Prof. Dr. Justin R. Pritchard, Department of Biomedical Engineering, Pennsylvania State University, University Park, PA 16802, USA.

[c] Dr. Tyler R. Mertens, Prof. Dr. Samuel G. Awuah, Department of Chemistry, University of Kentucky, Lexington, KY 40506, USA.

[d] Dr. Aude Ingels, Prof. Dr. Véronique Mathieu, Department of Pharmacotherapy and Pharmaceutics, Faculté de Pharmacie, Université libre de Bruxelles (ULB), Boulevard du Triomphe, 1050 Brussels, Belgium.

[e] Prof. Dr. Véronique Mathieu, ULB Cancer Research Center (UCRC), Université libre de Bruxelles (ULB), 1050 Brussels, Belgium.

[f] Dr. Marilin Koch, Dr. Michal O. Nowicki, Prof. Dr. Sean Lawler, Prof. Dr. Gilles Berger, Harvey Cushing Neuro-Oncology Laboratories, Department of Neurosurgery, Brigham and Women's Hospital, Harvard Medical School, Boston, MA 02115, USA.

\begin{abstract}
We disclose novel amphiphilic ruthenium and osmium complexes that auto-assemble into nanomedicines with potent antiproliferative activity by inhibition of mitochondrial respiration. The self-assembling units were rationally designed from the $[\mathrm{M}(p-$ cymene)(1,10-phenanthroline)Cl]PF ${ }_{6}$ motif (where $\mathrm{M}$ is either $\mathrm{Ru}$ " or Os") with an appended $\mathrm{C}_{16}$ fatty chain to achieve high cellular activity, nano-assembling and mitochondrial targeting. These amphiphilic complexes block cell proliferation at the sub-micromolar range and are particularly potent towards glioblastoma neurospheres made from patient-derived cancer stem cells. A subcutaneous mouse model using these glioblastoma stem cells highlights one of our $\mathrm{C}_{16}$ Os" nanomedicines as highly successful in vivo. Mechanistically, we show that they act as metabolic poisons, strongly impairing mitochondrial respiration, corroborated by morphological changes and damage to the mitochondria. A genetic strategy based on RNAi gave further insight on the potential involvement of microtubules as part of the induced cell death. In parallel, we present a careful examination of the structural properties of these new amphiphilic metal-based constructs, their reactivity and mechanism.
\end{abstract}

\section{Introduction}

Anticancer metal complexes have been given continuous attention since the discovery of cisplatin,,$^{[1]}$ and platinum-based drugs are still widely used today. ${ }^{[2-5]}$ Lack of selectivity leads to side effects ${ }^{[6]}$ and resistance mechanisms are still of major concern. ${ }^{7-9]}$ The success of platinum drugs have led to novel metal-based candidates and turned attention to neighboring transition elements. Among these, ruthenium, ${ }^{[10-12]}$ osmium, ${ }^{[13,14]}$ iridium, ${ }^{[15]}$ rhodium, ${ }^{[16]}$ titanium ${ }^{[17,18]}$ rhenium, ${ }^{[19,20]}$ and gold ${ }^{[21-24]}$ are under study. Development of pseudo-octahedral $\mathrm{Ru}^{\prime \prime}$ organometallic complexes has come to prominence in recent years. ${ }^{[13,25,26]}$ Anticancer activity of various Os complexes has been reviewed; ${ }^{[14]}$ among them few Os"-arene complexes have shown low micromolar in vitro activity. ${ }^{[27-30]}$
We have prepared original nano-constructs made from Rull and Os" pseudo-octahedral amphiphilic self-assembling units with a promising anticancer profile, including high cellular accumulation and metabolic targeting. Similarly to Lippard et al., ${ }^{[31]}$ we appended a $\mathrm{C}_{16}$ alkyl chain on the metal ligands, in an effort to address their usual low potency. ${ }^{[32-34]}$ The added lipophilicity resulted in a 100- to 300 -fold increase in the antiproliferative potency, ${ }^{[27,35,36]}$ with $\mathrm{IC}_{50}$ values typically far below the micromolar range, which is around 10 times more potent than for cisplatin. The lipophilic chain enables the spontaneously formation of nanostructures, binding to human serum albumin (HSA) and mitochondrial targeting, in an attempt to develop novel metabolic nanomedicines that specifically impair cancer cell types that rely on mitochondrial respiration. ${ }^{[37]}$ Self-formation of nanoparticles from bioactive metal complexes have been has been scarce in the literature; ${ }^{[38-41]}$ none were reported for osmium complexes.

This success led us to test these novel agents on glioblastoma stem cells (GSCs) and derived mouse models. Our metal-arene nanoassemblies were highly effective on patientderived GSC neurospheres. We demonstrate promising in vivo efficacy on a GBM mouse model, with $40 \%$ of the Os-treated mice as long-term survivor, and much slowed tumor growth for the others. Our final efforts focused on the cellular mechanisms conveying this promising anticancer profile, through an in-depth mechanistic study. Detailed cellular investigation and electron microscopy images indicated extensive mitochondrial damage, while an interfering RNA (RNAi) genetic assay further pointed towards tubulin and microtubules, highlighting an original mechanism of action that may involve multiple targets beside the mitochondria, and also operate by different mechanisms than classical anticancer drugs. 


\section{Results and Discussion}

Synthesis and solution-state conformation. The metal complexes were synthesized from the dinuclear $\mu$-chloro precursors and the $\mathrm{C}_{16}$-functionalized $\mathrm{N}, \mathrm{N}$-bidentate ligands, through ester and amide linkages at the C5 position (Scheme 1). This led to four amphiphilic assembling units (1-4) that differ by the metal center and the linking group. Parent compounds (5-6) were also prepared for validation of our design. All characterization data, including ${ }^{1} \mathrm{H}$ and ${ }^{13} \mathrm{C}$ NMR, IR, HRMS, HPLC purity and UV-Vis spectra can be found in the provided supporting information (Figures S1-33). Suitable crystals for Xray diffraction were unsuccessful despite numerous attempts, and we therefore investigated the ground-state geometries by DFT and NMR spectroscopy. This allowed determination of the relative position of the phenanthroline ligand to the arene moiety, and the conformation of the isopropyl group (Figure S34A-E). The most stable structure is found to have the chloride ligand pointing out in the same direction as the isopropyl group.
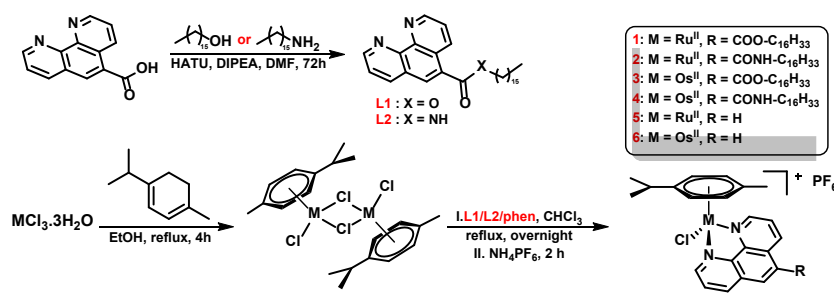

Scheme 2. Synthesis of the Ru" and Os" organometallic complexes with the $\mathrm{C}_{16}$ alkyl chains.

Self-assembling and binding to albumin. The amphiphilic design leading to self-assembling units was verified and aqueous solutions of 1-4 were examined by dynamic light scattering (DLS) to determine particle size and distribution, as well as the critical aggregation concentration (CAC). Hence, aggregation of 1-4 into nanoassemblies occurred at around 5 $\mu \mathrm{M}$ (Figure S35A). The median diameter of particles formed above the CAC were found around $100 \mathrm{~nm}$ with a positive surface potential, indicating the cationic nature of the nanoparticles (Figure S35B). In addition to the requested size for enhanced permeation and retention at tumor sites, ${ }^{[42]}$ this appears beneficial for cancer targeting: in contrast to normal cells, cancer cells overexpress anionic surface molecules such as phosphatidylserine, O-glycosylated mucins, sialilated gangliosides and heparan sulfates. ${ }^{[43-47]}$ Solutions of 2 and 4 were further analyzed by transmission electron microscopy (TEM), showing self-assembling into spherical nanoparticles (Figure $1 \mathrm{~A}-\mathrm{C}$ ) with a median diameter of around $85 \mathrm{~nm}$ for 2 and $155 \mathrm{~nm}$ for 4 (see distribution frequencies in Figure 1B-D), in agreement with the results obtained from DLS (Figure S35B).

Human serum albumin (HSA) is the most abundant plasma protein and is involved in the transport of drugs, metal ions, metal complexes and fatty acids through the bloodstream. ${ }^{[48]} \mathrm{We}$ supposed it might efficiently bind our C16 complexes and provide, together with the self-assembling, bloodstream transportation and long circulating times. ${ }^{[49]}$ We measured the binding parameters through the fluorescence quenching of a key Trp residue in the main drug binding site (Figure S45) ${ }^{[50,51]}$ using the modified Stern-Volmer equation (SI eq.1). ${ }^{[52]}$ Binding affinities were found two to three times higher for 1 (Ka $=4.610^{4}$ $\left.\mathrm{M}^{-1}\right)$ and $2\left(\mathrm{Ka}=5.610^{4} \mathrm{M}^{-1}\right)$ than for compound 5 (Table S1). Osmium complexes 3 and $4\left(\mathrm{Ka}=4.610^{4} \mathrm{M}^{-1}\right)$ bind slightly better to the protein than $6\left(\mathrm{Ka}=3.110^{4} \mathrm{M}^{-1}\right)$. Compound 2 was subsequently docked into HSA binding site I to visualize the interaction (Figure S44B). Binding thermodynamics were determined from the van't Hoff equation and the negative $\Delta G^{\circ}$ obtained for all compounds indicate a spontaneous association between the protein and the metal complexes. The $\Delta \mathrm{H}^{\circ}$ and $\Delta \mathrm{S}^{\circ}$ for all compounds remained negative (Table S1), indicative of van der Waals interactions and/or hydrogen bonding. ${ }^{[53]}$

Reactivity in aqueous solution. Aquation of halido complexes renders the metal center reactive towards DNA and other bionucleophiles. ${ }^{[54,55]}$ Experiments to examine the aquation of 5 and 6 have been previously published and reported experimental half-lives are $22 \min \left(k=1.8 \mathrm{~h}^{-1}\right)$ for 5 at $37^{\circ} \mathrm{C}^{[56]}$ and $9 \mathrm{~h}\left(\mathrm{k}=0.073 \mathrm{~h}^{-1}\right)$ for 6 at $45^{\circ} \mathrm{C} ;{ }^{[27]}$ Os complexes thus being more inert towards aquation than their $\mathrm{Ru}$ analogues. Aquation of 2 and 4 were followed in 7:3 DMSO- $d_{6} / D_{2} \mathrm{O}$ at $37^{\circ} \mathrm{C}$ for $72 \mathrm{~h}$. For compound 2, ${ }^{1} \mathrm{H}-\mathrm{NMR}$ revealed the formation of about $5 \%$ of the aqua complex (Figure S36B), which was confirmed by mass spectrometry (MS) (Figure S37). Equilibrium was reached after $24 \mathrm{~h}$ and no further changes were observed between 24 and $72 \mathrm{~h}$. The Os complex 4 appeared inert to aquation from ${ }^{1} \mathrm{H}-\mathrm{NMR}, \mathrm{UV}-\mathrm{Vis}$ and MS. The addition of silver $\left(\mathrm{AgPF}_{6}, 1.5\right.$ equiv.) to favor the chlorido/aqua ligand exchange resulted in complete aquation of the Ru complex 2 within $14 \mathrm{~h}$ at $37{ }^{\circ} \mathrm{C}\left(7.5 \mu \mathrm{M}\right.$ in $7: 3 \mathrm{DMF}-\mathrm{d}_{7} / \mathrm{D}_{2} \mathrm{O}$, Figure S36D), this aquation rate still being slower $\left(\mathrm{k}=0.28 \mathrm{~h}^{-1} ; \mathrm{t}_{1 / 2}=2.5 \mathrm{~h}\right.$, Figure S36F-G) than that of $\mathbf{5}$ without the help of the silver salt. Even after addition of $\mathrm{AgPF}_{6}$, the formation of aquated 4 remains negligible $(<1 \%$, Figure S36E). Formation of nanoparticles within UV-Vis samples did not allow us to determine aquation kinetics by this method. The UV-Vis solutions were analyzed by DLS to confirm the presence of such nanostructures (Figures S38-39). We proceeded to examine the aquation process by means of DFT using analogs of 2 and 4 bearing a methyl instead of a $C_{16}$. It appeared that the reaction is unfavored under standard conditions for both complexes (Figure S40), showing a rather high activation barrier (around $35 \mathrm{kcal} \mathrm{mol}^{-1}$ ) and unfavored free energy change (approximately $25 \mathrm{kcal} \mathrm{mol}^{-1}$ ). This contrasts with cisplatin for which aquation occurs readily (experimental $\Delta \mathrm{G}^{\ddagger}$ between 19.5 and $\left.21.5 \mathrm{kcal} \mathrm{mol}^{-1}\right)^{[57]}$ and is less unfavored $(\Delta G$ around $\left.5 \mathrm{kcal} \mathrm{mol}^{-1}\right)$. ${ }^{[57,58]}$

Glutathione $(\mathrm{GSH})$ is a major reducing agent and responsible for cellular detoxification of ROS and transition metals; ${ }^{[59]}$ cancer cells may become resistant to platinum drugs by increasing their GSH levels. ${ }^{[9]}$ The reaction of 2 in 7:3 DMSO$\mathrm{d}_{6} / \mathrm{D}_{2} \mathrm{O}$ with $\mathrm{GSH}$ was thus monitored by ${ }^{1} \mathrm{H}-\mathrm{NMR}$ for $72 \mathrm{~h}$ at $37^{\circ} \mathrm{C}$. A new set of signals with small intensities in the metalarene and phenanthroline regions indicates the formation of new species from 2. Incubation of 2 at $37^{\circ} \mathrm{C}$ for $24 \mathrm{~h}$ with 10 equiv. $\mathrm{GSH}$ and 1.5 equiv. $\mathrm{AgPF}_{6}$ allowed the formation of the $\mathrm{GSH}$ adduct, that is observed in the MS spectrum in small quantities in comparison with the starting compound $\mathbf{2}$, and in agreement with ${ }^{1} \mathrm{H}$-NMR (Figures S41-42). The $7.04 \mathrm{ppm}$ resonance (Figure $\mathrm{S} 41 \mathrm{~B})$ is characteristic of the $\mathrm{p}$-cymene release, ${ }^{[60]}$ which was also confirmed by MS with the presence of metal-GSH derivatives without their $p$-cymene and where the three coordination sites of the arene are bound to solvent molecules (Figure S42). ${ }^{[61-63]}$ Our Os analogue 4 was inert toward GSH (Figure S41C) but for compound 2, ${ }^{1} \mathrm{H}-\mathrm{NMR}$ and MS showed formation of GSSG, which could suppose a potential catalytic activity of $\mathbf{2}$ and $\mathbf{4}$ with GSH. Therefore, to highlight a potential 
role of GSH and thiols in the detoxification of $\mathbf{2}$ and $\mathbf{4}$, cytotoxicity assays on A549 and Hs683 were incubated during $72 \mathrm{~h}$ with the cysteine precursor $\mathrm{N}$-acetylcysteine (NAC) (Figure S43). In case of GSH depletion by the metal complexes 2 and $\mathbf{4}$, NAC would restore its levels, act as a ROS scavenger and lower the antiproliferative activity of the complexes. ${ }^{[64]}$ We observed a weak but significant $\mathrm{IC}_{50}$ increase on the $\mathrm{A} 549$ cell line but not for Hs683, which suggests that GSH-depletion either by a direct or indirect mechanism may play a small role but is not a major mechanism involved in the activity.

Reaction with DNA nucleobases were finally considered and complexes 2 and 4 were incubated with 10 equiv. of 9methylguanine (9MeG), 1.5 equiv. $\mathrm{AgPF}_{6}$ at $37^{\circ} \mathrm{C}$ for $24 \mathrm{~h}$ and analyzed by MS. Similarly to the aquation and $\mathrm{GSH}$ reactions, the $9 \mathrm{MeG}$ adduct was only observed for the Ru complex $\mathbf{2}$, and in small quantity (Figure S42C).

Theoretical and experimental evidence thus showed slow aquation and limited reactivity with $S$-donors. The reactivity of complexes $\mathbf{2}$ and $\mathbf{4}$ toward bionucleophiles (aquation, glutathione, 9-methylguanine and human serum albumin) can here be considered as low and may not fully explain the potent activity. Despite differential reaction kinetics towards hydrolysis and GSH, our Ru" and Os" amphiphilic complexes exhibited similar $\mathrm{IC}_{50}$ on a panel of cancer cell lines, which turned our attention to another possible mechanism of activation, comprising arene loss. We show oxidative loss of the arene moiety under physiological conditions in the presence of GSH, and this suggests it as a possible mechanism of reaction with intracellular targets, probably beside others. ${ }^{[65]}$ Figures and experimental details are given SI (Figures S36-43).
Cytotoxicity profiles and cellular accumulation. The in vitro anticancer activity was first determined by means of MTT assays (Figure S46) on five cancer cell lines; the non-small cell lung cancer cell line A549 (human lung carcinoma), MCF-7 (human breast adenocarcinoma), Hs683 (human glioma), B16F10 (murine skin melanoma) and M109 (murine lung carcinoma). The antiproliferative effects were compared to the parent phenanthroline compounds 5-6, ${ }^{[27,35,56]}$ with $\mathrm{IC}_{50}$ values in the range of $50-100 \mu \mathrm{M}$. In contrast, the $\mathrm{C}_{16}$ amphiphilic complexes 1-4 showed a dramatic increase of activity with $\mathrm{IC}_{50}$ values around $0.25 \mu \mathrm{M}$. This sub-micromolar growth inhibition is rare, and only a few half-sandwich $\mathrm{Ru}$ and Os complexes with such activities were reported to date..$^{[32,63,66]}$ It is also worth noting the improved antiproliferative activity of complexes 1-4 compared to cisplatin, notably 5- to 25 -fold enhancement in human cancer cell lines.

We hypothesize that the amphiphilic nature of these assembling units enhances cellular accumulation to improve the anticancer effect. The intracellular metal contents were thus determined for all compounds by ICP-MS on the A549 and B16F10 cell lines. This revealed that the alkyl chain induced a 10 - to 100 -fold increase on the penetration rate of the compounds (Figure 1E-F). Experimental LogP for the six complexes were determined using the shake-flask method and correlated to both the MTT $\mathrm{IC}_{50 \mathrm{~s}}$ and the cellular accumulation profiles $(1.49 \pm 0.06$ for $\mathbf{1}, 1.31 \pm 0.06$ for $2,1.57 \pm 0.08$ for $\mathbf{3}$, $0.54 \pm 0.05$ for $\mathbf{4},-0.90 \pm 0.02$ for 5 and $0.29 \pm 0.01$ for $\mathbf{6}$, Figure $1 \mathrm{G}$ ), increasing with the addition of the $C_{16}$ chain and inversely correlating to the $\mathrm{IC}_{50}$. They are similar to those observed for lipophilic $\mathrm{Pt}^{\mathrm{IV}}$ prodrugs. ${ }^{[31]}$ 
A

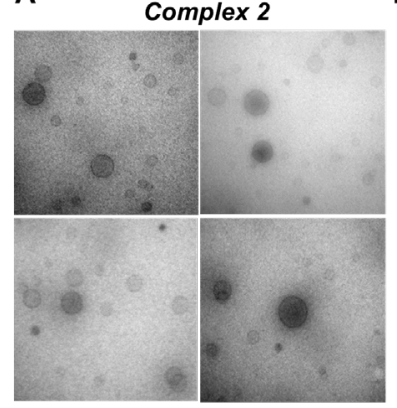

E

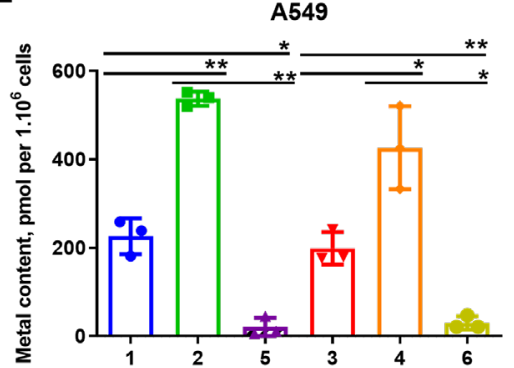

Frequency distribution - complex 2

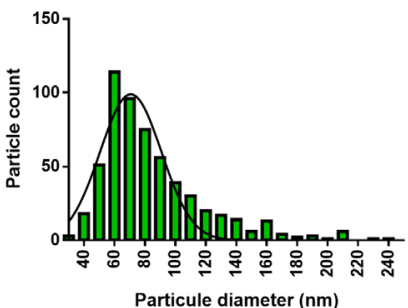

C

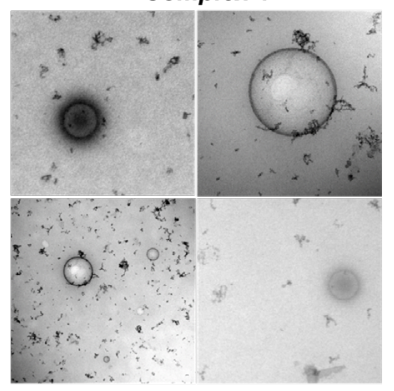

D

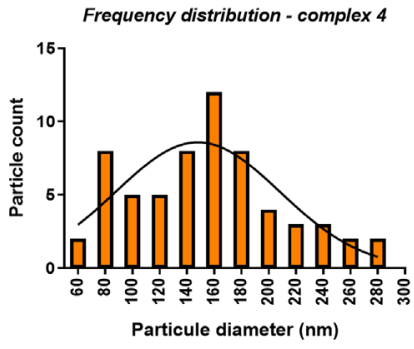

F
H

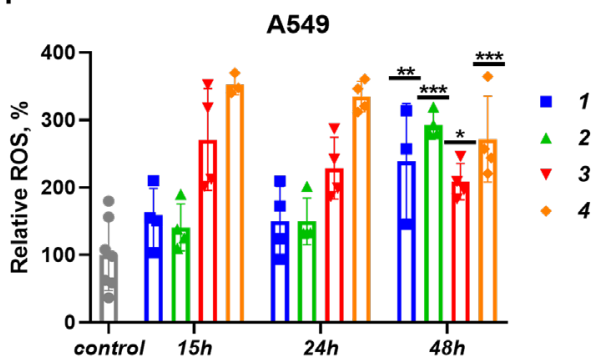

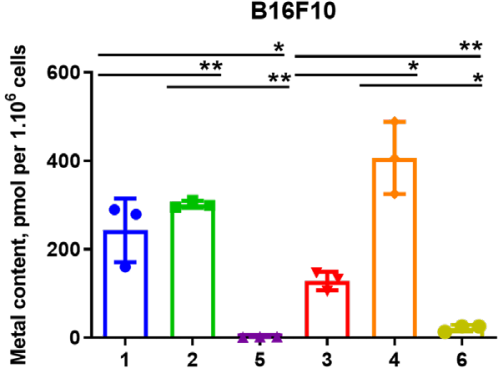

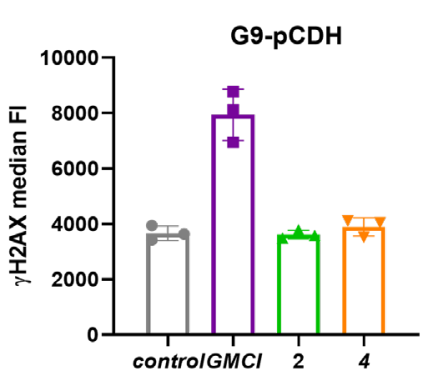

G

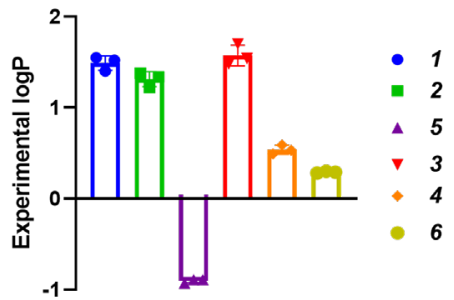

J

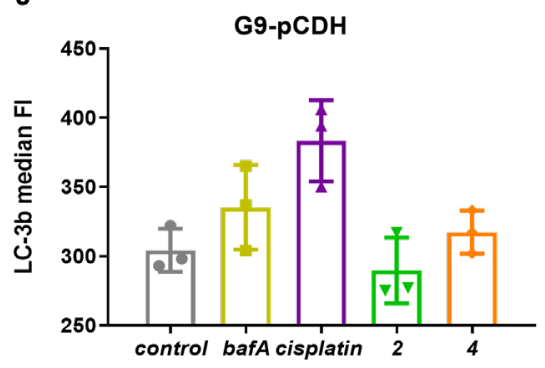

Figure 1. A-C. TEM images of 2 and 4 in aqueous solution $(75 \mu \mathrm{M})$, showing the spontaneous formation of spherical nanoparticles. B-D. Frequency distribution of particle size for 2 and 4. E-F. Intracellular metal contents for compounds 1-6 as determined by ICP-MS on the A549 and B16F10 cancer cell lines after $16 \mathrm{~h}$ exposure at $2 \mu \mathrm{M}$, highlighting the increased penetration of the amphiphilic compounds. G. Experimental Log P for complexes 1-6 determined by ICP-MS. H. ROS-production on A549 cells following treatment at 15,24 and $48 \mathrm{~h}$ for compounds $1-4, \mathrm{H}_{2} \mathrm{O}_{2}$ as positive control (Figure S15A), negative control cells were left untreated for $48 \mathrm{~h}$. P-values at $48 \mathrm{~h}$ relative to the control were generated using one-way ANOVA ( ${ }^{*} \mathrm{p}<0.05$, ${ }^{* *} \mathrm{p}<0.01$, $\left.{ }^{* * *} \mathrm{p}<0.001\right)$. I. $\mathrm{yH} 2 \mathrm{AX}$ levels determined on $\mathrm{G9pCDH}$ for compounds 2, 4 and $\mathrm{GMCl}$ (positive control) at their IC 50 for $48 \mathrm{~h}$. J. LC-3b levels determined on G9pCDH for compounds 2 , 4 , cisplatin and bafilomycin A (bafA, positive control, $100 \mathrm{nM}$ ) at their $\mathrm{IC}_{50}$ for $24 \mathrm{~h}$. 
Table 1. In vitro growth inhibition as determined by MTT assays on five cancer cell lines $\left(\mathrm{IC}_{50}, \mu \mathrm{M}\right)$.

\begin{tabular}{cccccc} 
Entry & A549 & Hs683 & MCF-7 & B16F10 & M109 \\
\hline 1 & $0.35 \pm 0.05$ & $0.35 \pm 0.04$ & $0.26 \pm 0.13$ & $1.18 \pm 0.45$ & $2.99 \pm 0.74$ \\
\hline 2 & $0.31 \pm 0.07$ & $0.25 \pm 0.04$ & $0.54 \pm 0.11$ & $3.04 \pm 1.67$ & $15.0 \pm 6.20$ \\
\hline \hline 3 & $0.28 \pm 0.03$ & $0.26 \pm 0.11$ & $0.22 \pm 0.07$ & $0.88 \pm 0.52$ & $8.98 \pm 1.33$ \\
\hline 4 & $0.69 \pm 0.07$ & $1.58 \pm 0.81$ & $1.01 \pm 0.33$ & $2.33 \pm 0.23$ & $2.96 \pm 0.08$ \\
\hline 5 & $65.4 \pm 13.1$ & $55.2 \pm 16.5$ & $75.2 \pm 3.8$ & $70.6 \pm 16.5$ & $>100$ \\
\hline 6 & $82.8 \pm 1.4$ & $77.9 \pm 10.4$ & $73.1 \pm 5.2$ & $>100$ & $>100$ \\
\hline \hline cisplatin & $1.72 \pm 0.16$ & $1.12 \pm 0.20$ & $8.75 \pm 0.60$ & $9.38 \pm 0.75$ & $0.97 \pm 0.19$
\end{tabular}

Cellular effects. First, changes in cell motility and mitotic function upon treatment were followed using quantitative videomicroscopy (QVM). After $24 \mathrm{~h}$ treatment with 1-4, A549 cells elongated without entering mitosis or apoptosis, suggesting a cytostatic activity (Figure S47). Additional details from the QVM experiments are given in SI (Figure S48).

Apoptotic cell death and cell cycle arrest at the $G_{2} / M$ phase are known to occur following treatment with DNA-targeting platinum compounds. ${ }^{[67]}$ Considering that apoptosis was also induced by some Ru and Os compounds, ${ }^{[68,69]}$ we decided to investigate it. ${ }^{[70]}$ Compounds 1-4 revealed no apoptosis after 72 $\mathrm{h}$ at their $\mathrm{IC}_{50}$ (annexin V/propidium iodide staining $(\mathrm{PI})$, Figure S49A), which confirmed observations from QVM. No changes in the cell cycle profile were either observed, suggesting a DNAdamage independent activity (Figure S49B). We thus looked at DNA damage through histone phosphorylation and $\mathrm{YH} 2 \mathrm{AX}$ levels. Low levels of $\mathrm{YH} 2 \mathrm{AX}$ were observed with $\mathbf{2}$ and $\mathbf{4}$, unlike gene-mediated cytotoxic immunotherapy $(\mathrm{GMCl})$ which is known to induce DNA damages, ${ }^{[71]}$ used here as positive control (Figure 1I). We then turned to oxidative damage, and ROS were measured at 15, 24 and $48 \mathrm{~h}$ after treatment. A significant increase in ROS production was observed for the Os" compounds $\mathbf{3}$ and $\mathbf{4}$, with respect to $\mathrm{Ru}$ "l complexes $\mathbf{1}$ and $\mathbf{2}$ at $24 \mathrm{~h}$, and all compounds increased ROS production at $48 \mathrm{~h}$ (Figure $1 \mathrm{H}$ ). Similar observations were made on the $\mathrm{Hs} 683$ glioma cell line but ROS reached their highest level after $24 \mathrm{~h}$ (Figure S50C-D).

Acridine orange $(A O)$ staining after $48 \mathrm{~h}$ treatment with $\mathrm{Ru}^{\prime \prime}$ compounds 1 and 2 revealed critical accumulation of acidic vesicular organelles in the perinuclear region when compared to untreated cells (Figure S51), suggesting an autophagic process. ${ }^{[72]}$ Cells treated with $\mathbf{3}$ and $\mathbf{4}$ showed lower levels of AO when compared to the Ru complexes, and did not adopt the spherical shape, indicating of lower critical damage and weaker cell toxicity. Positive AO staining and lack of apoptotic cell led us to examine LC-3b, a specific marker of autophagy. G9pCDH GSCs treated with compounds $\mathbf{2}$ and $\mathbf{4}$ however did not display changes in LC-3b expression (Figure 1J).

Untreated A549 cells (Figure 2A) have numerous lamellar bodies (LB) in the cytoplasm as well as functional mitochondria and endoplasmic reticulum (ER). Unlike controls, cells treated with 2 and 4 showed a significant decrease of LB, probably consecutive to the impaired metabolism and protein synthesis, which would arise from damaged mitochondria and deformed
ER (Figure 2B-C). In both treated conditions, the Golgi apparatus was kept intact. Treatment with 4 (Figure 2C) showed similar damage with enlarged and elongated mitochondria, fragmented ER and the presence of multivesicular bodies. In contrast to cellular features observed under apoptotic conditions and by comparison with untreated cells, the integrity of the cytoplasmic and nucleic membranes were relatively well conserved following treatment. ${ }^{[73]}$ Similar observations were made with autophagy-inducing Ru" $\beta$-carboline complexes. ${ }^{[74]}$
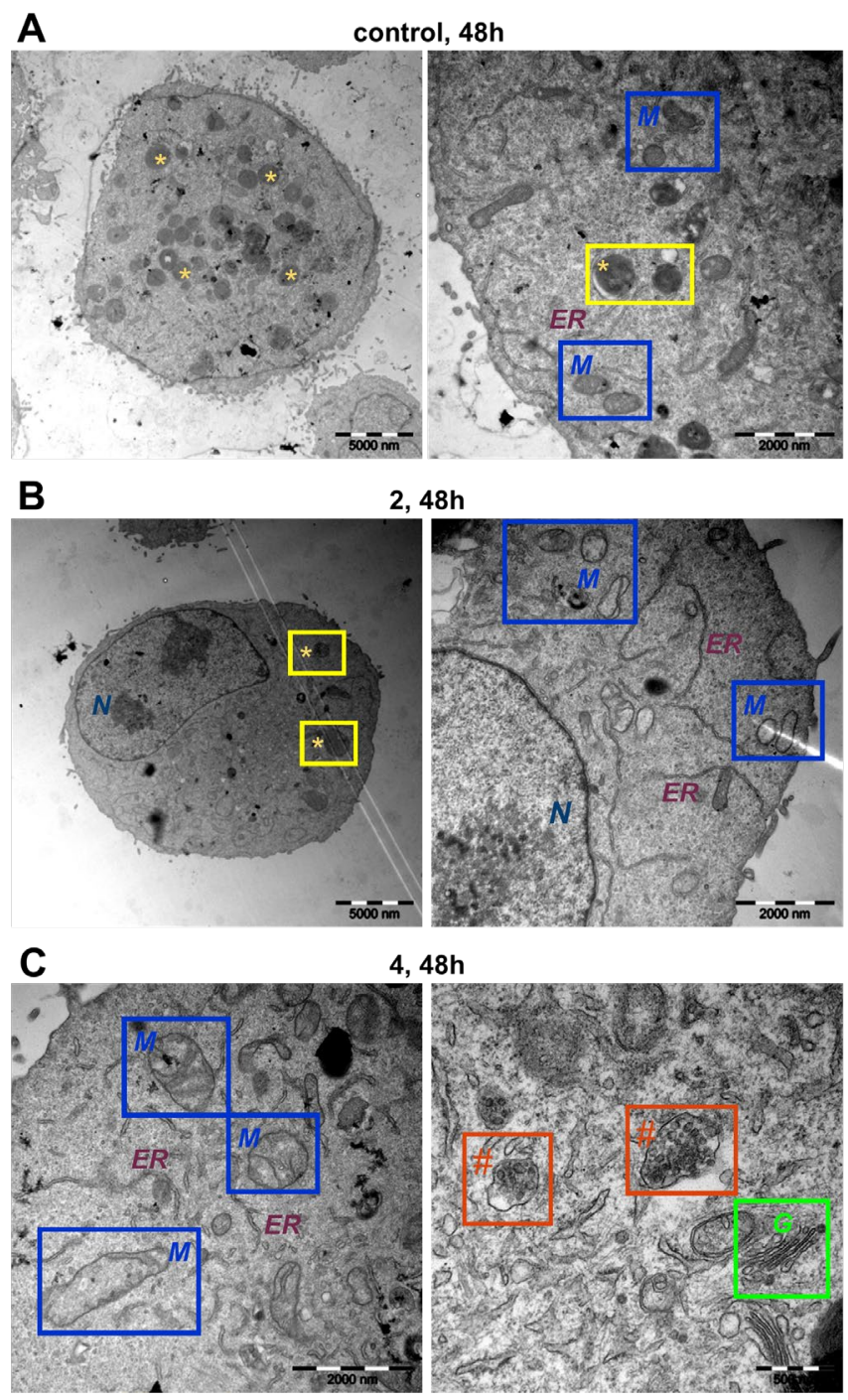

Figure 2. Transmission electron microscopy images of $A 549$ cells treated with 2 and 4 at their $\mathrm{IC}_{50}$ during $48 \mathrm{~h}$ and fixed in glutaraldehyde and cacodylate. Yellow * (lamellar bodies), orange \# MVB (multivesicular bodies), M (mitochondria), ER (endoplasmic reticulum), G (Golgi apparatus) and N (nucleus). Mitochondria in treated cells ( $B$ and $C$ ) showed an advanced degenerated state characterized by enlarged structures, loss of inner membrane integrity and loss of cristae, in comparison to untreated cells (A).

Targeting mitochondrial respiration. Results obtained from this preliminary assessment allowed us to consider metabolism and the mitochondria as central in the mechanism of action of these new nano-assemblies made of amphiphilic complexes. We then treated A549 cells with compounds $\mathbf{2}$ and $\mathbf{4}$ via pneumatic injection in a Mito-stress assay and analyzed the changes in oxygen consumption rate (OCR). Known oxidative 
phosphorylation (OXPHOS) inhibitors were used: oligomycin, a complex $\mathrm{V}$ inhibitor, to view the basal OCR, FCCP (an uncoupler) used to observe the maximum OCR, and rotenone/antimycin A (Rot/AA), a complex I/III inhibitor respectively which then completely shuts down the electron transport chain (ETC). The addition of these inhibitors in sequential order allows for extrapolation of key bioenergetic parameters (Figure 3A-B). We observed that compounds 2 and 4 at concentrations as low as $300 \mathrm{nM}$ significantly inhibited maximal respiration and spare respiratory capacity (Figure $3 \mathrm{C}-\mathrm{E}$ and S52A-C). The acute loss of these two parameters signifies an immediate impact on mitochondria homeostasis. A significant loss of ATP production and a decrease in coupling efficiency were also observed for both compounds at $300 \mathrm{nM}$, suggesting that mitochondrial OXPHOS efficiency is acutely compromised (Figure 3D-F and S52B-D). Further bioenergetic parameters were extracted from the real time ATP-rate assay to give contributions of both glycolytic and mitochondria-linked ATP on A549 cells with compounds 2 and 4 (Figure 3G-I and S53). Both compounds drastically reduced mitochondrial ATP production and at the $\mathrm{IC}_{50}$, only glycolytic energy remains, indicative of a shift in metabolic dependency. We then sought to determine the level of mitochondrial ROS (mtROS) after exposure to compounds 2 and $\mathbf{4}$ at both their $\mathrm{IC}_{50}$ and twice their $\mathrm{IC}_{50}$ for 24 h (Figure 3H-J and S54). 2 and 4 significantly increase mtROS; up to three times compared to the control and up to twice compared to the known uncoupler (FCCP). Finally, we exposed A549 cells with compounds 2 and 4 at their $I_{50}$ for $24 \mathrm{~h}$ to analyze the effect on the mitochondrial membrane potential (MMP, Figure 3K). Both compounds cause severe loss of MMP, which is emphasized by the loss of red fluorescence (PE-A FACS channel, Figure 3K). All together these results revealed a strong metabolic effect on bioenergetic health, which could directly target cancer cells and their high energy dependency, essential to sustain tumor proliferation, progression and to evade immunosurveillance. ${ }^{[75]}$ The rapid onset of $\mathrm{mtROS}$ production in conjunction with OXPHOS deficiency suggests a direct interaction with mitochondria and perturbation of the metabolic capacity of the cells.
RNA interference signatures. We performed multivariate genetic measurements to further probe underlying cellular mechanisms at play. This "ab initio" method, which makes no assumptions, is based on gene deletion effects that are compared to a vast set of known anticancer drugs, using supervised and unsupervised machine learning. K-nearest neighbors (KNN), principal component analysis (PCA) and tdistributed stochastic neighbor embedding (t-SNE) clustering were then applied. To assess gene deletion effects on druginduced cell death, murine lymphoma $(E \mu-M y c)$ cell lines were separately infected with eight shRNA-GFP tagged vectors targeting critical proteins: p53, ATR, Chk1, Chk2, ATX, DNA-PK, BOK and Bim4 (Figure S55). A resistance index (RI; knocked down versus wild type, see SI) was then determined on the eight cell lines at three different drug concentrations (adjusted to achieve the $I C_{80}, I C_{85}$ and $I C_{90}$, Figure S56A-B). Cisplatin and doxorubicin were used as positive controls and were correctly classified as DNA cross-linking agents and topoisomerases II inhibitors, respectively. The obtained dendrogram (Figure 4A) emphasizes three subgroups based on cellular responses: (1) cisplatin and doxorubicin, (2) complex 2 and (3), complexes 1, 3 and 4. Unlike cisplatin and doxorubicin, p53 and Chk2 are not involved in the antitumor activity of compounds 1, 3 and 4; 2 being the only complex in the series to be p53 and Chk2 dependent, but not as strongly as for cisplatin and doxorubicin. Compounds 1, 3 and 4 have negative Rls for the p53 knocked down cell line, in contrast to cisplatin, doxorubicin and 2 for which p53 mutations produce resistant phenotypes. We can here foresee an advantage at targeting p53-mutant tumors. The 2D t-SNE (Figure 4B) distinctly highlights the close proximity of 2 to the central dogma disruptor category, that includes a wide variety of anticancer drugs such as DNA transcription and replication inhibitors, mTOR inhibitors and proteins synthesis inhibitors. The t-SNE map shows $\mathbf{1}, \mathbf{3}$ and $\mathbf{4}$ to be close to the mitotic spindle poisons, the histone deacetylases (HDAC) group and DNA methyltransferase (DNMT) inhibitors. 

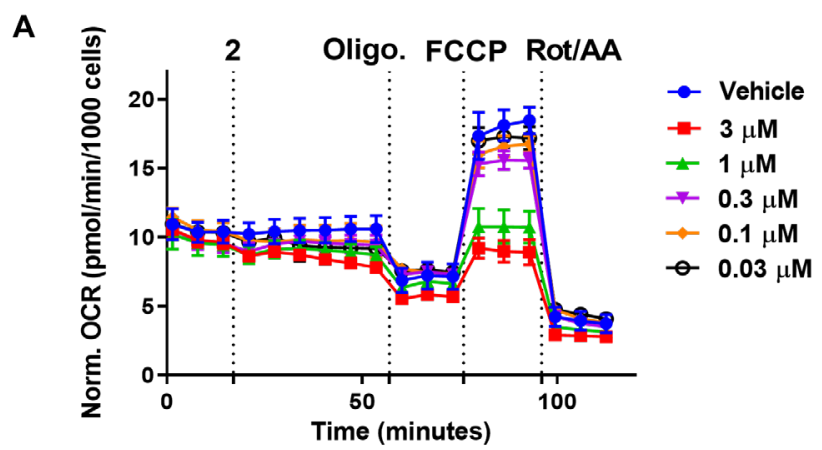

C
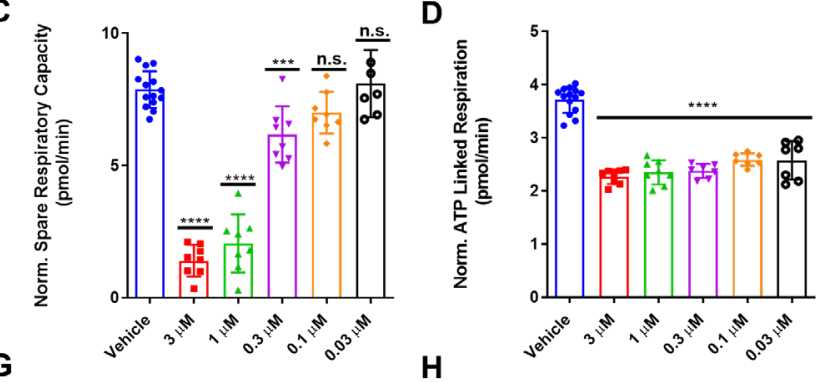

H
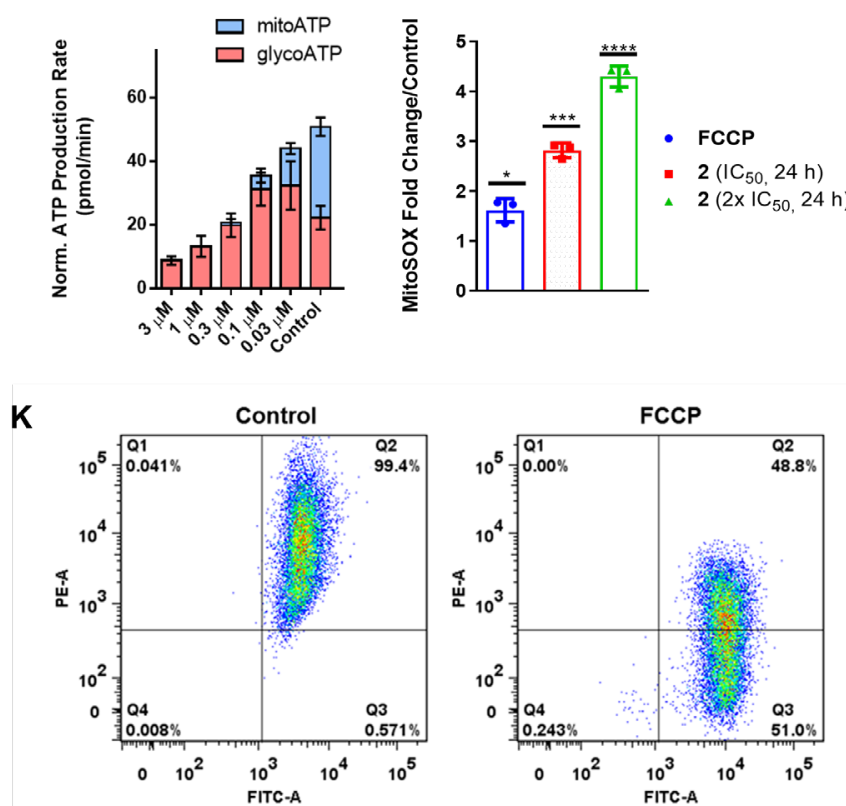

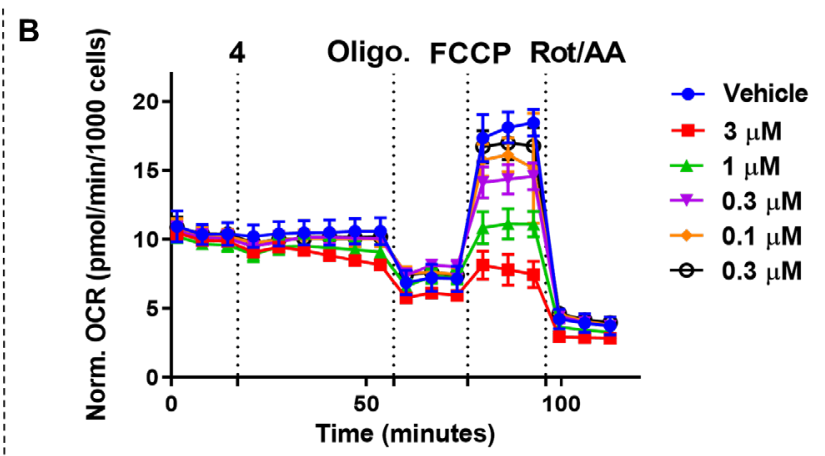

E
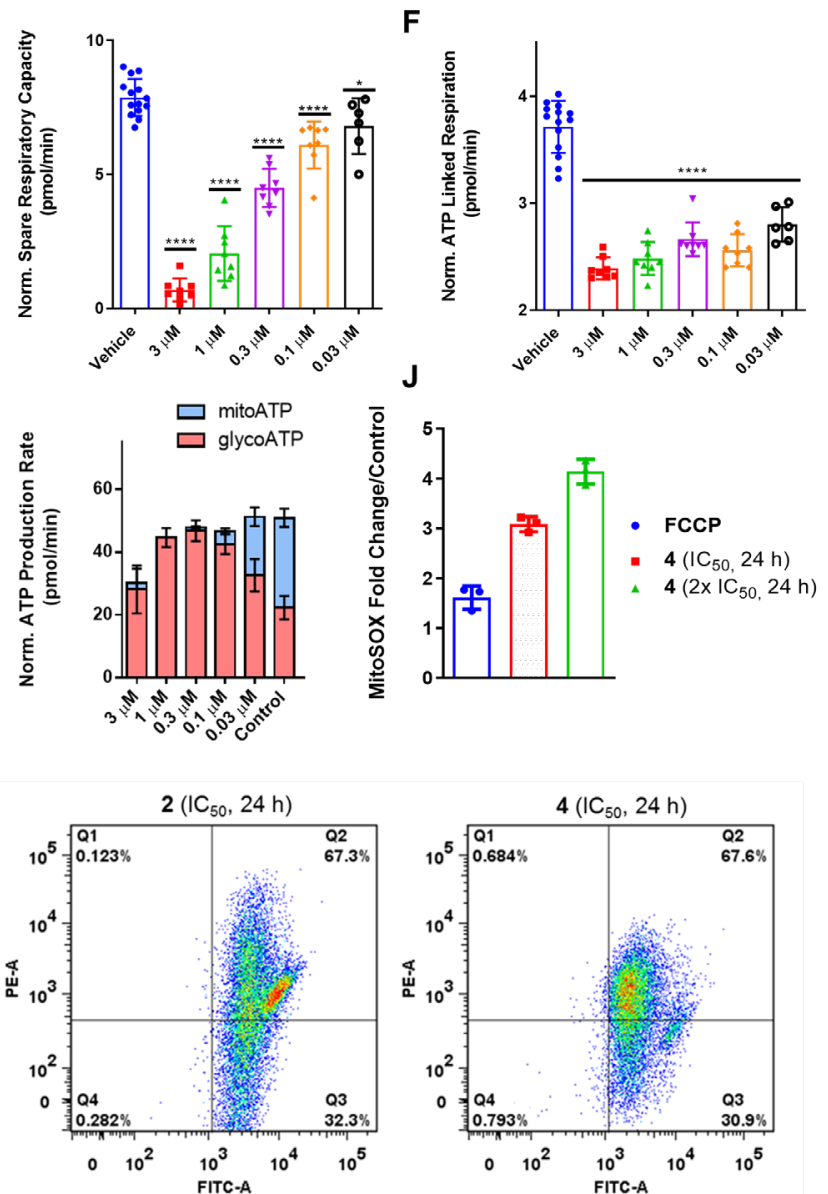

Figure 3. Seahorse XFe96 Cell Mito Stress profile for compounds 2 (A) and $4(B)$. Bioenergetic parameters were extracted from the oxygen consumption rate (OCR) plot: Spare Respiratory Capacity and ATP-linked OCR for compounds 2 (C-D) and 4 (E-F) on A549 cells. ATP-rate was extracted from the OCR/PER ratio to give contributions of glycolytic and mitochondrial ATP for compounds 2 (G) and 4 (I). Measurement of mtROS by flow cytometry (MitoSox dye) on A549 cell line with compounds $2(\mathrm{H})$ and $4(\mathrm{~J})$ at their $\mathrm{IC}_{50}$ and twice their $\mathrm{IC}_{50}$ for $24 \mathrm{~h}$. Mitochondrial membrane potential (MMP) measurement by flow cytometry $(\mathrm{JC}-1$ staining) on A549 cell line with compounds $2(\mathrm{~K})$ and $4(\mathrm{~K})$ at their IC50 for $24 \mathrm{~h}$. FCCP as positive control.

From KNN predictions, compounds 1, 3 and 4 are categorized as spindle poisons and compound $\mathbf{2}$ as a nucleic acid synthesis inhibitor, which partially correlates with the t-SNE predictions. However, a kernel density estimate determined insignificant $p$ values (> 0.1) for compounds 1-4 (suggesting an alternative mechanism of action, different from those of "pure" mitotic spindle poisons for compounds $\mathbf{1}, \mathbf{3}$ and $\mathbf{4}$ and different than nucleic acid synthesis inhibitor for compound 2). Proper classification from supervised predictions is indeed obtained if $p$ values are significant and, if not, it would predict a novel or balanced mechanism of action. ${ }^{[76-78]}$ Vinca alkaloids inhibit microtubule polymerization and mitotic spindle destabilizers have an inhibitory effect on the 
A

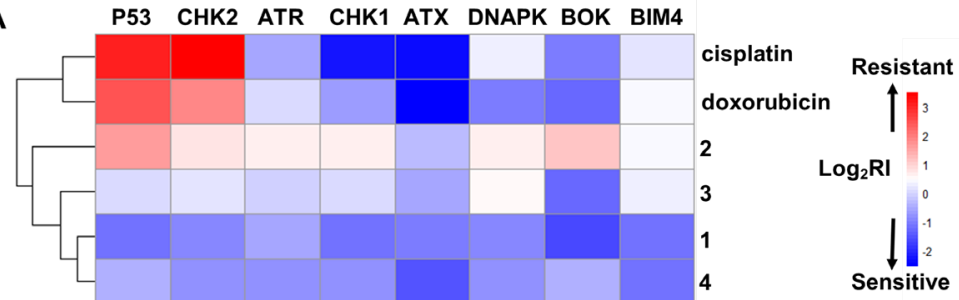

C

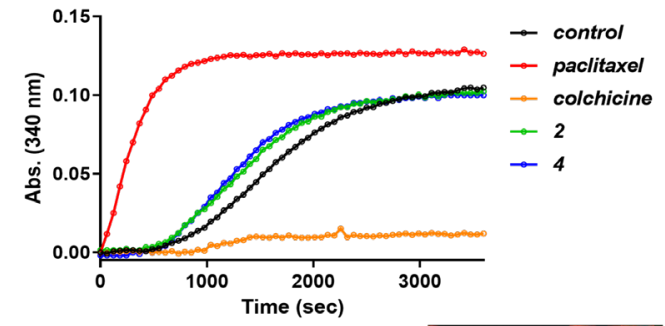

B
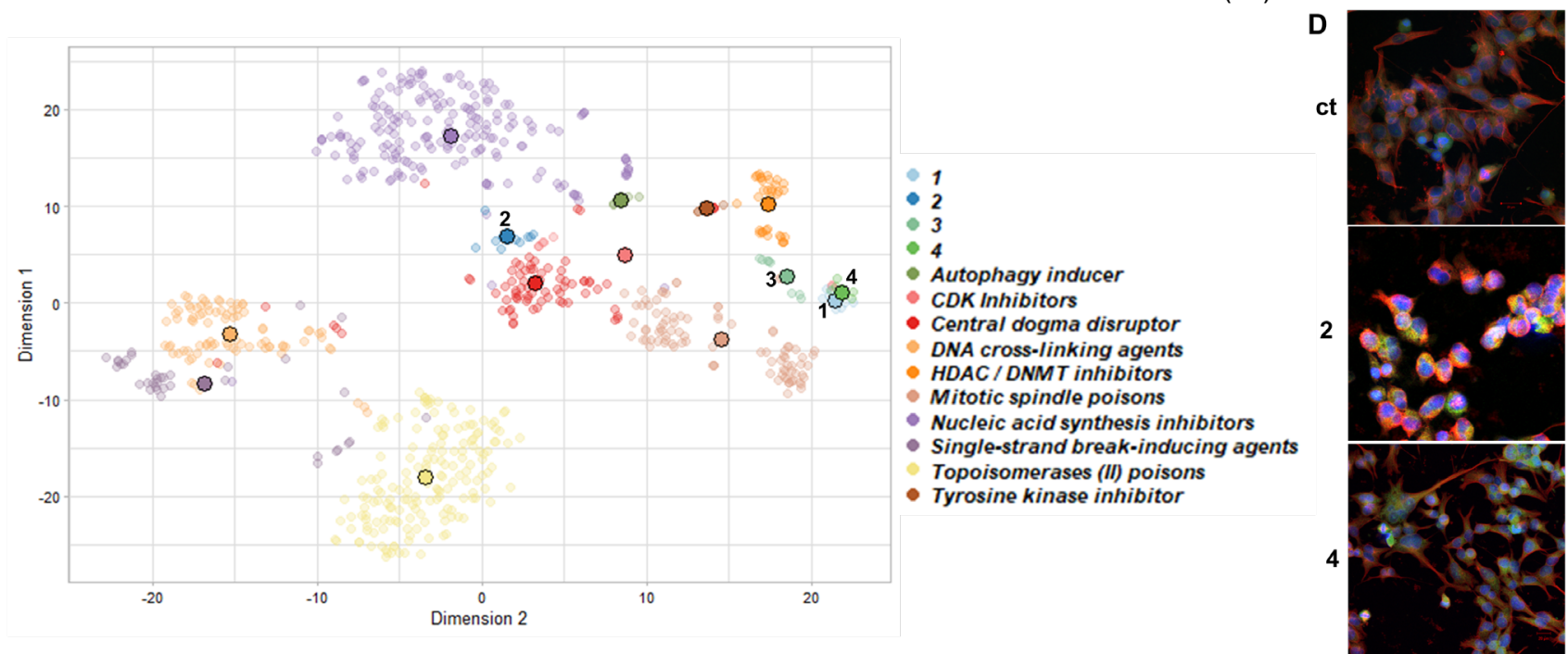

Figure 4. A. Heatmap of RI calculated from experimental RI as determined on eight E $\mu$-myc knockdown cell lines. B. Plot generated by the tSNE algorithm with the RI obtained for multiple approved antitumor drugs. Centroid points of each area are highlighted by a black circle. C. Degree of tubulin polymerization was followed determined for 2 and by means of absorbance measurements at $340 \mathrm{~nm}$ in a 96-well plate at $10 \mu \mathrm{M}, 37^{\circ} \mathrm{C}$, and for $1 \mathrm{~h}$. Paclitaxel and colchicine were used respectively as positive and negative controls. D. Fluorescent microscopic images of fixed G9pCDH cells immunostained for tubulin (red) and the nucleus (blue) after treatment with 2 and 4 . Cells were treated $\mathrm{IC}_{50} / 2$ for $24 \mathrm{~h}$.

autophagy process by blocking maturation of autophagosomes, ${ }^{[79,80]}$ which in our case may explain the lack of induction of autophagy, low LC-3b levels (Figure $1 \mathrm{~J}$ ) and low abundance of late autophagic structure (Figure 2B-C). Similarly, Sadler et al. reported in 2013 a series of osmium iminopyridine complexes sharing similar cancer cell selectivity patterns to vinblastine, using the COMPARE algorithm, but with no direct effect on tubulin polymerization. ${ }^{[81]}$ More recently, $\mathrm{Ru}^{\text {"l }}$ polypyridyl complex (RPC2) appears to act as microtubule stabilizers in vitro but not as taxane derivatives do. The same study also revealed intriguing similarities with our series of amphiphilic complexes, without disruption of the cell cycle at the $\mathrm{IC}_{50}$ and the induction of mitochondrial damage. ${ }^{[82]} \mathrm{Ru}^{\text {Il }}$ arene complexes targeting plectin, a cytolinker protein associated to non-mitotic microtubules, were recently synthesized and studied by means of proteomics. ${ }^{[83]}$

According to the shRNA data that pointed out microtubules as a potential target, we sought to determine the effect of 2 and 4 on cytoskeleton dynamics (Figure 4C). Compounds 2 and 4 seem to have a slight stabilizing effect on tubulin polymerization, yet much lower than the positive control paclitaxel. Vmax values of 2 and 4 (3.4 and $3.6 \mathrm{OD} / \mathrm{min}$ respectively) are closer to the negative control $V \max (0.9 \mathrm{OD} / \mathrm{min})$ than to paclitaxel $(12.3$ $\mathrm{OD} / \mathrm{min})$. Vmax is increased by four with paclitaxel and decreased approximatively by a 3.5 -fold with colchicine. Complementary to the tubulin polymerization assay, immunostaining experiments were able to provide additional information. Untreated cells revealed the spreading of microtubules around the nucleus and throughout the cytoplasm. In contrast, microtubules in cells treated with $\mathbf{4}$ appeared more condensate around the nucleus and stretched out through their cytoskeleton extremities, a morphology change that was already observed from QVM. Cells treated with 2 adopted a spherical shape indicative of cell death (Figure 4D), emphasizing the higher toxicity of $\mathrm{Ru}^{\prime \prime}$ compound $\mathbf{2}$ compared to the Os" compound $\mathbf{4}$, as seen in the $\mathrm{AO}$ staining experiment. These results support the idea of an alternative mechanism of action in which microtubules could be involved but probably not as the main target, that would remain disruption of cellular metabolism and mitochondrial respiration. 
A

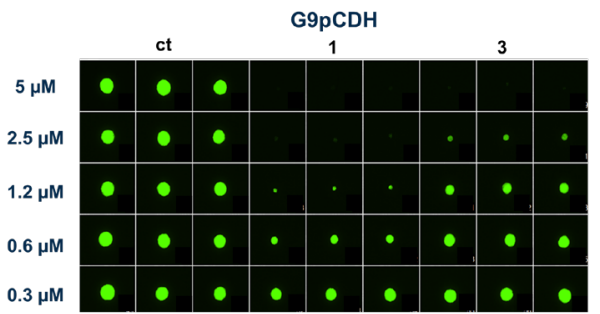

B

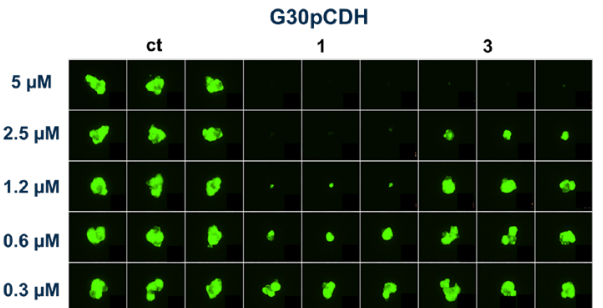

1 - G9pCDH

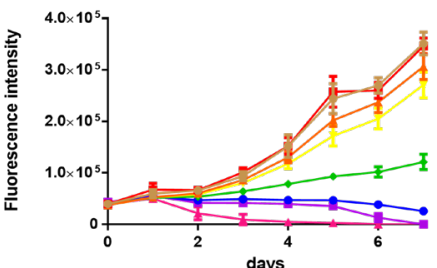

$\mathrm{IC}_{50}(\mathrm{TMZ}, 72 \mathrm{~h})=7 \pm 3 \mu \mathrm{M}$

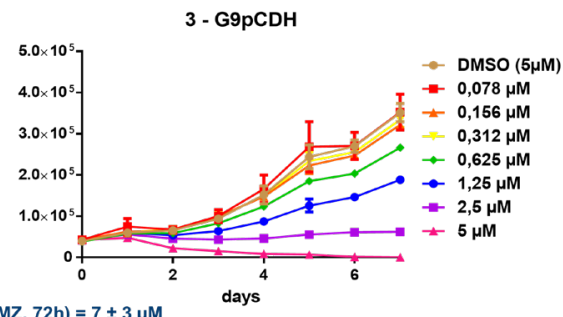

$\operatorname{IC}_{50}(1,72 \mathrm{~h})=0.5 \quad \mathrm{IC}_{50}$ (cisplatin, $\left.72 \mathrm{~h}\right)=0.6 \pm 1.5 \mu \mathrm{M} \quad \mathrm{IC}_{50}(3,72 \mathrm{~h})=2.4 \mu \mathrm{M}$

1 - G3OPCDH

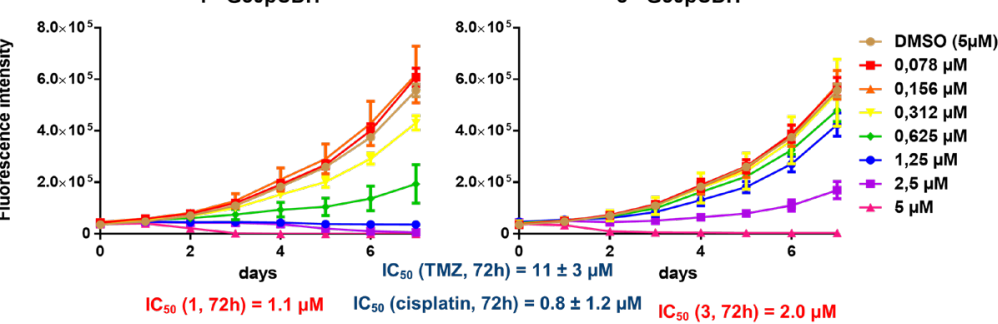

C

Day 7

Day 21

Day 28

Day 35

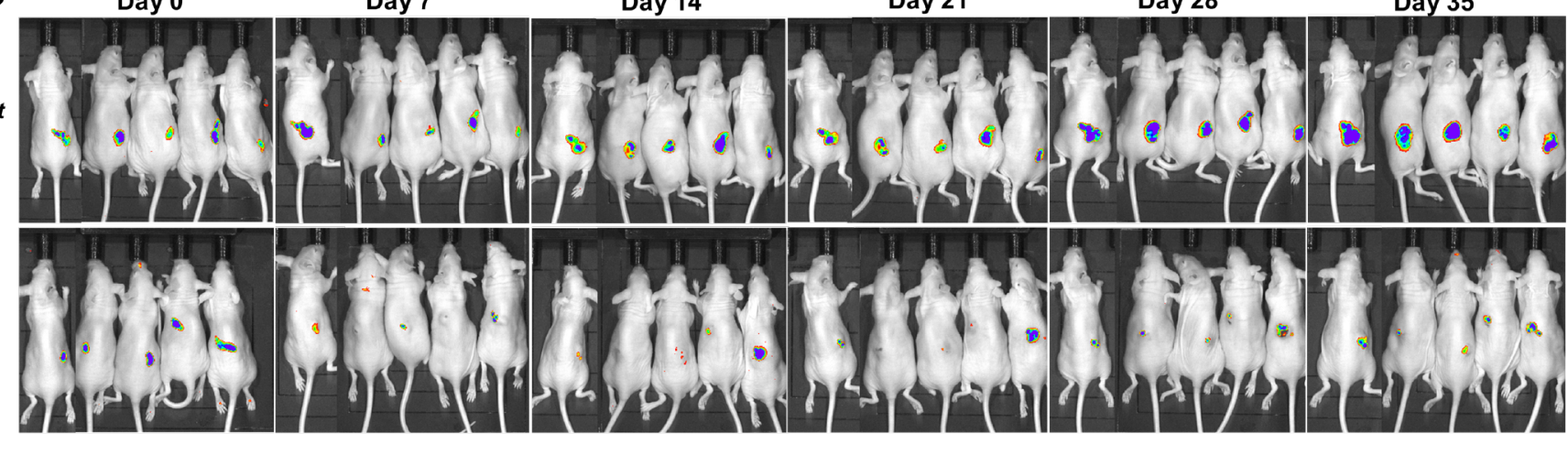

D

Flank tumors $\mathrm{Gg}^{\mathrm{pCDH}}$

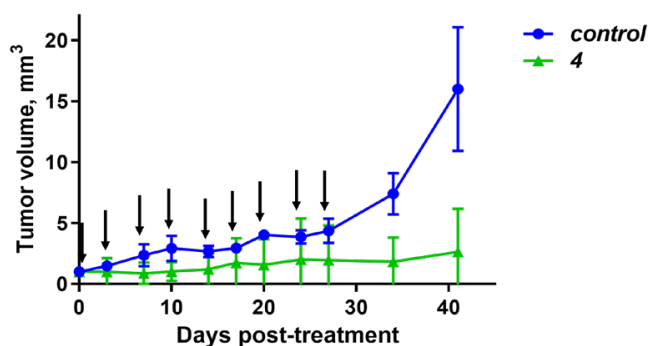

E

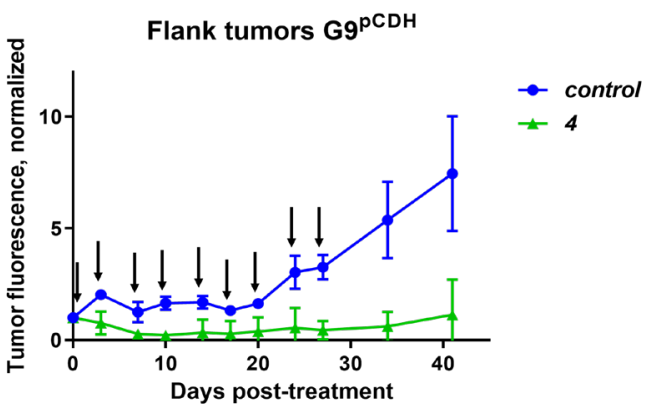

Figure 5. A-B. Images of the G9pCDH and G30pCDH fluorescent neurospheres from the GILA assays for 1 and 3 and their associated plots of fluorescence over time at different concentrations. C. In vivo images of the control group and mice treated with 4. D/E. Graphic representations of tumor volume and tumor fluorescence over 42 days. Each arrow represents a subcutaneous injection of compound 4, twice a week for 28 days.

Glioblastoma models. Glioblastoma remains one of the most aggressive and challenging forms of cancer. The presence of glioblastoma initiating cells in the tumor microenvironment provides self-renewing populations of tumor cells bearing enhanced tumorigenic properties. ${ }^{[84,85]}$ Current chemotherapies, such as temozolomide (TMZ) and cisplatin, have been shown to be less efficient towards these populations and despite reducing the tumor mass, would allow cancer relapse from resistant GSCs. ${ }^{[86,87]}$ Owing to the amphiphilic nature of the compounds, their metabolic disruptor profile, and our recent work on glioblastoma and GSCs, ${ }^{[88]}$ we anticipated that they could be potent in this model. This assumption was supported by the evidence that GSCs are highly dependent on the OXPHOS machinery compared to more differentiated GBM cells to assure their proliferation. ${ }^{809,90]}$ Thereby, targeting CSGs seems particularly appropriate for our energy disruptor nanoassemblies. The use of 3D-spheroid models made of GSCs is insightful to better depict in vivo characteristics and therefore these models are powerful tools for in vitro drugs screening assays. ${ }^{\left[{ }^{[1]}\right.}$ Hence, we used the growth in low attachment assay (GILA), ${ }^{[92]}$ to evaluate the antiproliferative activity of complexes 1 and 3 on two GFP-expressing patient-derived GSCs, i.e. G9pCDH and 
G30pCDH. The $\mathrm{IC}_{50}$ obtained on G9 GSCs for $\mathbf{1}$ and $\mathbf{3}$ were 0.5 $\mu \mathrm{M}$ and $2.4 \mu \mathrm{M}$ respectively, which is far more potent than TMZ, the standard of care for glioblastoma $\left(I_{50}=7 \mu \mathrm{M}\right.$ ) (Figure $5 \mathrm{~A})$. The amphiphilic complexes, reached the potency of cisplatin $\left(\mathrm{IC}_{50}\right.$ around $\left.1 \mu \mathrm{M}\right)$ and surpassed recently reported $\mathrm{Os}^{\mathrm{VI}}$ nitrido compounds, being at least 10 times more potent. ${ }^{[88]}$ Compounds $1\left(\mathrm{IC}_{50}=1.1 \mu \mathrm{M}\right)$ and $3\left(\mathrm{IC}_{50}=2.0 \mu \mathrm{M}\right)$ display similar antiproliferative potency to cisplatin $\left(\mathrm{IC}_{50}=0.8 \pm 1.2 \mu \mathrm{M}\right)$ on the more resistant G30-derived spheroids, but they appear more active than $\mathrm{TMZ}\left(\mathrm{IC}_{50}=11 \pm 3 \mu \mathrm{M}\right.$, Figure $\left.5 \mathrm{~B}\right){ }^{[88]}$ We can note that at $5 \mu \mathrm{M}$ there were no surviving cells and that compound 1 was more potent than its osmium analog 3 on both GSC lines.

Nude mice were implanted subcutaneously with $\mathrm{G} 9 \mathrm{pCDH}$ cells and the fluorescence was monitored together with tumor size. Compounds 2 and $\mathbf{4}$ were injected intratumorally at the indicated timepoints (Figure 5C-D-E). Tumor volume and fluorescence markedly increased in the control group, unlike the Os-treated group that showed no tumor growth over time (Figure $5 \mathrm{C}-\mathrm{D}-\mathrm{E})$, confirming its promising in vitro antiproliferative activity and neurosphere potency. $40 \%$ of the mice from the Os-treated group were long-term survivors without visible signs of remaining tumor cells. The group initially treated with the $\mathrm{Ru}$ compound $\mathbf{2}$ was discarded due to the appearance of edema after injection and the apparent lack of efficacy. These in vivo experiments thus highlight again a relative weaker toxicity of the Os" compound 4 in comparison to the Ru" compound 2, which caused edema and necrosis at the injection site, thereby limiting the frequency of injection, and was therefore not able to prevent tumor growth.

We have thus developed here antiproliferative metal-arene units that spontaneously assemble into nanostructures under physiological conditions, resulting in particles of the requested size for good permeation and retention at tumor sites. ${ }^{[42]}$ The four newly synthesized amphiphilic organometallic complexes bear high antiproliferative activity on human cancer cell lines A549, MCF-7 and Hs683, owing to the $\mathrm{C}_{16}$-modification of the $\mathrm{N}, \mathrm{N}$-bidentate ligand. This lipophilic tail dramatically enhanced the cell penetration of the complexes, conferring previously scarce in vitro potency to metal-arene pseudo-octahedral $\mathrm{Ru}$ and Os compounds. Unaltered cell cycle and QVM suggest that extensive DNA damage is not responsible for the activity. The increase in ROS contents in the A549 and Hs683 cancer cell lines indicates some degree of cellular stress, but rather as a secondary effect. Genetic assays based on shRNA knocked downs pointed out similarities between cellular responses triggered by mitotic spindle poisons and our amphiphilic constructs, but apparently without direct interaction with tubulin. From the t-SNE maps, we also noticed spatial proximity with HDAC/DNMT inhibitors, and our amphiphilic complexes could therefore share similitudes in terms of cellular response with some epigenetic modulators.

The in vitro efficacy of our metal-organic nanoassemblies surpassed that of cisplatin and although cancer stem cells are usually less sensitive to anticancer drugs, ${ }^{[86,87]} \mathbf{1}$ and $\mathbf{3}$ have demonstrated promising activity on the GSC neurospheres, which are known to be resistant to conventional chemotherapies. Glioma cells are highly dependent on the OXPHOS machinery for ATP production, ${ }^{[93,94]}$ and in vivo investigations on a subcutaneous glioma model confirmed the efficacy of the osmium compound $\mathbf{4}$, that achieved complete tumor regression. TEM revealed mitochondrial damage, and a detailed in vitro assay showed direct OXPHOS inhibition. We indeed demonstrate potent disruption of cell metabolism and mitochondrial function, with loss of mitochondrial ATP, increase of $\mathrm{mtROS}$ and mitochondrial membrane depolarization. Recent reports on $\mathrm{Cu}^{\text {Il }}$ complexes functionalized with a mitochondriapenetrating peptide showed activity on breast cancer stem cell mostly through induction of mitochondrial membrane depolarization and generation of intracellular ROS. ${ }^{[95]}$ Cationic gold $\left(\mathrm{Au}^{\prime}\right.$ and $\left.\mathrm{Au} \mathrm{u}^{\mathrm{III}}\right)$ complexes were also shown to accumulate in mitochondria and strongly alter mitochondrial structure and function, being particularly potent on aggressive breast cancer cell line. ${ }^{[21,96]}$ All together, this suggests that metallodrugs bearing a positive charge and balanced lipophilicity can accumulate inside mitochondria, offering promising alternatives to tackle tumor cells via non-nuclear or genomic pathways.

\section{Conclusion}

To summarize, we disclosed here a novel series of nanoassembling and highly potent $\mathrm{Ru}$ and Os metal-arene complexes that are active on in vitro and in vivo glioblastoma stem cells models, through multi-targeted cellular disruptions that comprise poisoning of the cytoskeleton and mitochondrial processes. This original metabolic and multi-target profile from self-assembling nanoparticles, active on cancer stem cells, will be profitable to avoid resistances and relapse of tumor growth after treatment, warranting further in vivo studies on cancer models.

\section{Acknowledgements}

M.M. thanks Véronique Megalizzi and Michel Gelbcke for helpful discussions and guidance on the analysis of video microscopy experiments, the team of the Analytical Platform of the Faculty of Pharmacy (ULB) for the record of MS spectra and the team of G-time laboratory (ULB) for the ICP-MS experiments. We would also like to thank Dr. Tomoko Sengoku and Mr. Michael Alstott for the support with our redox metabolism experiments, supported by the shared resource(s) of the University of Kentucky Markey Cancer Center (P30CA177558).

Funding: This research was partially funded by $\mathrm{NCl}$ R50 CA243706-02 for MON, by the Fédération Wallonie-Bruxelles (EG/MA/JCD/CBV 19-24) for M.M. and by the Belgian Brain Tumor Support (BBTS) for V.M.; G. B. was the recipient of an FRS-FNRS award.

Keywords: Metabolic poisons - Cancer stem cells - shRNA profiling $\bullet$ nano-assembling $\bullet$ antitumor complexes

B. Rosenberg, L. Van Camp, T. Krigas, Nature 1965, 205, 698-699. Ronald S. Go; Alex A. Adjei, J Clin Oncol 2012, 17, 409-422.

[3] B. Desoize, C. Madoulet, Crit. Rev. Oncol. Hematol. 2002, 42, 317325 .

[4] L. Kelland, Nat. Rev. Cancer 2007, 7, 573-84.

[5] L. H. Einhorn, J. Clin. Oncol. 1990, 8, 1777-1781.

[6] A.-M. Florea, D. Büsselberg, Cancers (Basel). 2011, 3, 1351-1371.

[7] S. Hector, W. Bolanowska-Higdon, J. Zdanowicz, S. Hitt, L. 
Pendyala, Cancer Chemother. Pharmacol. 2001, 48, 398-406.

[8] D. J. Stewart, Crit. Rev. Oncol. Hematol. 2007, 63, 12-31.

[9] L. Galluzzi, L. Senovilla, I. Vitale, J. Michels, I. Martins, O. Kepp, M. Castedo, G. Kroemer, Oncogene 2012, 31, 1869-1883.

[10] S. Medici, M. Peana, V. M. Nurchi, J. I. Lachowicz, G. Crisponi, M. A. Zoroddu, Coord. Chem. Rev. 2014, 1-22.

[11] C. Mari, G. Gasser, Chim. Int. J. Chem. 2015, 69, 176-181.

[12] A. Bergamo, C. Gaiddon, J. H. M. Schellens, J. H. Beijnen, G. Sava, J. Inorg. Biochem. 2012, 106, 90-99.

[13] S. M. Meier-Menches, C. Gerner, W. Berger, C. G. Hartinger, B. K. Keppler, Chem. Soc. Rev. 2018, DOI 10.1039/C7CS00332C.

[14] M. Hanif, M. V. Babak, C. G. Hartinger, Drug Discov. Today 2014, 19, 1640-1648.

[15] Z. Liu, P. J. Sadler, Acc. Chem. Res. 2014, 47, 1174-85.

[16] C. H. Leung, H. J. Zhong, D. S. H. Chan, D. L. Ma, Coord. Chem. Rev. 2013, 257, 1764-1776.

[17] M. Cini, T. D. Bradshaw, S. Woodward, Chem. Soc. Rev. 2017, 46, 1040-1051.

[18] F. Caruso, M. Rossi, C. Pettinari, Expert Opin. Ther. Pat. 2001, 11, 969-979.

[19] A. Leonidova, G. Gasser, 2014

[20] E. B. Bauer, A. A. Haase, R. M. Reich, D. C. Crans, F. E. Kühn, Coord. Chem. Rev. 2019, 393, 79-117.

[21] R. T. Mertens, W. C. Jennings, S. Ofori, J. H. Kim, S. Parkin, G. F. Kwakye, S. G. Awuah, JACS Au 2021, 1, 439-449.

[22] R. T. Mertens, S. Parkin, S. G. Awuah, Chem. Sci. 2020, 11, 10465-10482.

[23] S. Gukathasan, S. Parkin, S. G. Awuah, Inorg. Chem. 2019, 58, 9326-9340.

[24] J. H. Kim, E. Reeder, S. Parkin, S. G. Awuah, Sci. Rep. 2019, 9, 118.

[25] R. E. Aird, J. Cummings, a a Ritchie, M. Muir, R. E. Morris, H. Chen, P. J. Sadler, D. I. Jodrell, Br. J. Cancer 2002, 86, 1652-1657.

[26] C. Scolaro, A. Bergamo, L. Brescacin, R. Delfino, M. Cocchietto, G. Laurenczy, T. J. Geldbach, G. Sava, P. J. Dyson, J. Med. Chem. 2005, 48, 4161-4171.

[27] A. F. A. Peacock, A. Habtemariam, S. A. Moggach, A. Prescimone, S. Parsons, P. J. Sadler, V. Uni, W. M. Road, E. Eh, Inorg. Chem. 2007, 46, 2966-2967.

[28] S. D. Shnyder, Y. Fu, A. Habtemariam, S. H. Van Rijt, P. A. Cooper, P. M. Loadman, P. J. Sadler, Medchemcomm 2011, 2, 666-668.

[29] R. J. Needham, C. Sanchez-Cano, X. Zhang, I. Romero-Canelón, A. Habtemariam, M. S. Cooper, L. Meszaros, G. J. Clarkson, P. J. Blower, P. J. Sadler, Angew. Chemie - Int. Ed. 2017, 56, 1017-1020.

[30] J. M. Hearn, I. Romero-Canelón, A. F. Munro, Y. Fu, A. M. Pizarro, M. J. Garnett, U. McDermott, N. O. Carragher, P. J. Sadler, Proc. Natl. Acad. Sci. 2015, 201500925.

[31] Y.-R. Zheng, K. Suntharalingam, T. C. Johnstone, H. Yoo, W. Lin, J. G. Brooks, S. J. Lippard, J. Am. Chem. Soc. 2014, 136, 8790-8.

[32] J. Palmucci, F. Marchetti, R. Pettinari, C. Pettinari, R. Scopelliti, T. Riedel, B. Therrien, A. Galindo, P. J. Dyson, Inorg. Chem. 2016, 55, 11770-11781.

[33] F. R. Svensson, M. Matson, M. Li, P. Lincoln, Biophys. Chem. 2010, 149, 102-106.

[34] F. Khan, B. Therrien, G. Süss-fink, O. Zava, P. J. Dyson, J. Organomet. Chem. 2013, 730, 49-56.

[35] L. Colina-vegas, W. Villarreal, M. Navarro, C. Rodrigues, D. Oliveira,
A. E. Graminha, P. Ivo, S. Maia, V. M. De, A. G. Ferreira, M. Regina, A. A. Batista, 2015, 153, 150-161.

[36] S. B. Olga, N. Robert, J. D. Ana, 2012, 1033-1051.

[37] T. M. Ashton, W. Gillies McKenna, L. A. Kunz-Schughart, G. S. Higgins, Clin. Cancer Res. 2018, 24, 2482-2490.

[38] W. Sun, S. Li, B. Häupler, J. Liu, S. Jin, W. Steffen, U. S. Schubert, H. J. Butt, X. J. Liang, S. Wu, Adv. Mater. 2017, 29, DOI 10.1002/adma.201603702.

[39] P. Kołoczek, A. Skórska-Stania, A. Cierniak, V. Sebastian, U. K. Komarnicka, M. Płotek, A. Kyzioł, Eur. J. Pharm. Biopharm. 2018, 128, 69-81.

[40] S. Estalayo-Adrián, S. Blasco, S. A. Bright, G. J. McManus, G. Orellana, D. C. Williams, J. M. Kelly, T. Gunnlaugsson, Chem. Commun. 2020, 56, 9332-9335.

[41] C. M. Clavel, E. Păunescu, P. Nowak-Sliwinska, P. J. Dyson, Chem. Sci. 2014, 5, 1097-1101.

[42] J. Fang, H. Nakamura, H. Maeda, Adv. Drug Deliv. Rev. 2011, 63, 136-151.

[43] F. Schweizer, Eur. J. Pharmacol. 2009, 625, 190-194.

[44] M. D. Burdick, A. Harris, C. J. Reid, T. Iwamura, M. A. Hollingsworth, J. Biol. Chem. 1997, 272, 24198-24202.

[45] I. J. Fidler, A. J. Schroit, J. Connor, C. D. Bucana, I. J. Fidler, Cancer Res. 1991, 51, 3062-3066.

[46] J. Kleeff, T. Ishiwata, A. Kumbasar, H. Friess, M. W. Büchler, A. D. Lander, M. Korc, J. Clin. Invest. 1998, 102, 1662-1673.

[47] H. S. Lee, C. B. Park, J. M. Kim, S. A. Jang, I. Y. Park, M. S. Kim, J. H. Cho, S. C. Kim, Cancer Lett. 2008, 271, 47-55.

[48] S. Curry, P. Brick, N. P. Franks, Biochim. Biophys. Acta - Mol. Cell Biol. Lipids 1999, 1441, 131-140.

[49] P. Sathyadevi, P. Krishnamoorthy, N. S. P. Bhuvanesh, P. Kalaiselvi, V. Vijaya, N. Dharmaraj, Eur. J. Med. Chem. 2012, 55, 420-431.

[50] J. Ghuman, P. A. Zunszain, I. Petitpas, A. A. Bhattacharya, M. Otagiri, S. Curry, J. Mol. Biol. 2005, 353, 38-52.

[51] F. A. Beckford, Int. J. Inorg. Chem. 2010, DOI 10.1155/2010/975756.

[52] S. S. Lehrer, Biochemistry 1971, 10, 3254-3263.

[53] N. Cacita, S. Nikolaou, J. Lumin. 2016, 169, 115-120.

[54] F. Wang, A. Habtemariam, E. P. L. van der Geer, R. Fernández, M. Melchart, R. J. Deeth, R. Aird, S. Guichard, F. P. A. Fabbiani, P. Lozano-Casal, I. D. H. Oswald, D. I. Jodrell, S. Parsons, P. J. Sadler, Proc. Natl. Acad. Sci. U. S. A. 2005, 102, 18269-74.

[55] A. F. A. Peacock, A. Habtemariam, R. Fernández, V. Walland, F. P. A. Fabbiani, S. Parsons, R. E. Aird, D. I. Jodrell, P. J. Sadler, J. Am. Chem. Soc. 2006, 128, 1739-1748.

[56] S. Betanzos-lara, O. Novakova, R. J. Deeth, A. M. Pizarro, G. J. Clarkson, B. Liskova, V. Brabec, P. J. Sadler, A. Habtemariam, J. Biol. Inorg. Chem. 2012, 17, 1033-1051.

[57] J. Raber, C. Zhu, L. A. Eriksson, Mol. Phys. 2004, 102, 2537-2541.

[58] J. R. Perumareddi, A. W. Adamson, J. og Phys. Chem. 1967, 3774, 414-420.

[59] R. D. anf D. F. Ganesaratnam K. Balendiran, Cell Biochem. Funct. 2004, 22, 343-352.

[60] S. J. Dougan, M. Melchart, A. Habtemariam, S. Parsons, P. J. Sadler, Inorg. Chem. 2006, 45, 10882-10894.

[61] H. Tobita, K. Hasegawa, J. Josephus, G. Minglana, L. Luh, M. Okazaki, H. Ogino, Organometallics 1999, 2058-2060.

[62] L. Delaude, S. Delfosse, A. Richel, A. Demonceau, A. F. Noels, 2003, 1526-1527. 

Organometallics 2007, 6643-6652.

[64] A. Miyajima, J. Nakashima, M. Tachibana, K. Nakamura, M. Hayakawa, M. Murai, Japanese J. Cancer Res. 1999, 90, 565-570. M. P. Sullivan, M. K. Nieuwoudt, G. A. Bowmaker, N. Y. S. Lam, D. Truong, D. C. Goldstone, C. G. Hartinger, Chem. Commun. 2018, DOI 10.1039/C8CC02433B.

[66] Y. Fu, A. Habtemariam, A. M. Pizarro, S. H. Van Rijt, D. J. Healey, P. A. Cooper, S. D. Shnyder, G. J. Clarkson, P. J. Sadler, J. Med. Chem. 2010, 53, 8192-8196. C. M. Sorenson, M. A. Barry, A. Eastman, J. Natl. Cancer Inst. 1990 82.

[68] I. Romero-Canelón, L. Salassa, P. J. Sadler, J. Med. Chem. 2013, 56, 1291-300.

[69] G. Mühlgassner, C. Bartel, W. F. Schmid, M. A. Jakupec, V. B. Arion, B. K. Keppler, J. Inorg. Biochem. 2012, 116, 180-187.

[70] C. P. Tan, Y. Y. Lu, L. N. Ji, Z. W. Mao, Metallomics 2014, 6, 978 995.

[71] M. C. Speranza, C. Passaro, F. Ricklefs, K. Kasai, S. R. Klein, H. Nakashima, J. K. Kaufmann, A. K. Ahmed, M. O. Nowicki, P. Obi, A. Bronisz, E. Aguilar-Cordova, L. K. Aguilar, B. W. Guzik, X. Breakefield, R. Weissleder, G. J. Freeman, D. A. Reardon, P. Y. Wen, E. A. Chiocca, S. E. Lawler, Neuro. Oncol. 2018, 20, 225-235.

[72] S. Fulda, D. Kögel, Oncogene 2015, 34, 5105-5113.

[73] Y. Kondo, S. Kondo, Autophagy 2006, 85-90.

[74] C. Tan, S. Lai, S. Wu, S. Hu, L. Zhou, Y. Chen, M. Wang, Y. Zhu, J. Med. Chem. 2010, 7613-7624.

[75] P. E. Porporato, N. Filigheddu, J. M. B. S. Pedro, G. Kroemer, L. Galluzzi, Cell Res. 2018, 28, 265-280.

[76] H. Jiang, J. R. Pritchard, R. T. Williams, D. A. Lauffenburger, M. T. Hemann, Nat. Chem. Biol. 2010, 7, 1-9.

[77] J. R. Pritchard, P. M. Bruno, M. T. Hemann, D. A. Lauffenburger, Mol. Biosyst. 2013, 9, 1604-1619.

[78] J. R. Pritchard, P. M. Bruno, L. A. Gilbert, K. L. Capron, D. A. Lauffenburger, M. T. Hemann, PNAS 2012, 110, 170-179.

[79] H. Vakifahmetoglu-norberg, H. Xia, H. Vakifahmetoglu-norberg, H. Xia, J. Yuan, J. Clin. Invest. 2015, 125, 5-13.

[80] A. L. Kovacs, A. Reith, P. O. Seglen, Exp. Cell Res. 1982, 137, 191-201.

[81] Y. Fu, R. Soni, M. J. Romero, A. M. Pizarro, L. Salassa, G. J. Clarkson, J. M. Hearn, A. Habtemariam, M. Wills, P. J. Sadler, Chemistry 2013, 19, 15199-209.

[82] N. Alatrash, F. H. Issa, N. S. Bawazir, S. J. West, K. E. Van ManenBrush, C. P. Shelor, A. S. Dayoub, K. A. Myers, C. Janetopoulos, E. A. Lewis, F. M. MacDonnell, Chem. Sci. 2020, 11, 264-275.

[83] S. M. Meier, D. Kreutz, L. Winter, M. H. M. Klose, K. Cseh, T. Weiss, A. Bileck, B. Alte, J. C. Mader, S. Jana, A. Chatterjee, A. Bhattacharyya, M. Hejl, M. A. Jakupec, P. Heffeter, W. Berger, C. G. Hartinger, B. K. Keppler, G. Wiche, C. Gerner, Angew. Chemie - Int. Ed. 2017, 56, 1-6.

[84] S. K. Singh, C. Hawkins, I. D. Clarke, J. A. Squire, J. Bayani, T. Hide, R. M. Henkelman, M. D. Cusimano, P. B. Dirks, Nature 2004, 432, 396-401.

[85] R. Galli, E. Binda, U. Orfanelli, B. Cipelletti, A. Gritti, S. De Vitis, R. Fiocco, C. Foroni, F. Dimeco, A. Vescovi, Cancer Res. 2004, 64, 7011-7021.
Zheng, M. T. Hemann, S. J. Lippard, J. Am. Chem. Soc. 2014, 136, 14413-14416.

[87] J. Lathia, S. Mack, Genes ... 2015, 29, 1203-1217.

[88] G. Berger, K. Grauwet, H. Zhang, A. M. Hussey, M. O. Nowicki, D. I. Wang, E. A. Chiocca, S. E. Lawler, S. J. Lippard, Cancer Lett. 2018. 416, 138-148.

[89] M. Janiszewska, M. L. Suvà, N. Riggi, R. H. Houtkooper, J. Auwerx, V. Clément-Schatlo, I. Radovanovic, E. Rheinbay, P. Provero, I. Stamenkovic, Genes Dev. 2012, 26, 1926-1944.

[90] E. Vlashi, C. Lagadec, L. Vergnes, T. Matsutani, K. Masui, M. Poulou, R. Popescu, L. Della Donna, P. Evers, C. Dekmezian, K. Reue, H. Christofk, P. S. Mischel, F. Pajonka, Proc. Natl. Acad. Sci. U. S. A. 2011, 108, 16062-16067.

[91] T. Ishiguro, H. Ohata, A. Sato, K. Yamawaki, T. Enomoto, K. Okamoto, Cancer Sci. 2017, 108, 283-289.

[92] A. Rotem, A. Janzer, B. Izar, Z. Ji, J. G. Doench, L. A. Garraway, K. Struhl, Proc. Natl. Acad. Sci. U. S. A. 2015, 112, 5708-13.

[93] Y. Shi, S. K. Lim, Q. Liang, S. V. Iyer, H. Y. Wang, Z. Wang, X. Xie, D. Sun, Y. J. Chen, V. Tabar, P. Gutin, N. Williams, J. K. De Brabander, L. F. Parada, Nature 2019, 567, 341-346.

[94] D. Sighel, M. Notarangelo, S. Aibara, A. Re, G. Ricci, M. Guida, A. Soldano, V. Adami, C. Ambrosini, F. Broso, E. F. Rosatti, S. Longhi, M. Buccarelli, Q. G. D’Alessandris, S. Giannetti, S. Pacioni, L. RicciVitiani, J. Rorbach, R. Pallini, S. Roulland, A. Amunts, I. Mancini, A. Modelska, A. Quattrone, Cell Rep. 2021, 35, 109024.

[95] K. Laws, G. Bineva-Todd, A. Eskandari, C. Lu, N. O'Reilly, K. Suntharalingam, Angew. Chemie - Int. Ed. 2018, 57, 287-291.

[96] S. G. Awuah, J. H. Kim, S. Ofori, R. T. Mertens, S. Parkin, ChemMedChem 2021, DOI 10.1002/cmdc.202100233. 